I. М. Коржов, П. Ф. Щапов, Р. П. Мигущенко, О. Ю. Кропачек

Національний технічний університет «Харківський політехнічний інститут», Харків

\title{
ОЦІНКА ТА ДОСЛІДЖЕННЯ ЧУТЛИВОСТІ, ДИСКРИМІНУЮЧИХ ТА ДІАГНОСТИЧНИХ ВЛАСТИВОСТЕЙ ПОКАЗНИКІВ АВТОКОГЕРЕНТНОСТІ
}

\begin{abstract}
Проведена оцінка чутливості кореляційно-спектральної моделі показника автокогерентності багатовимірного термодинамічного процесу, оцінка дискримінуючих властивостей показників автокогерентності при класифікації вібраційних процесів, дослідженно діагностичні властивості складових показника автокогерентності на прикладі теплових та вібросигналів реального промислового об’єкту контролю та діагностування. На прикладі теплових динамічних процесах показана ефективність розробленого показника автокогерентності $\rho_{W}$ для задач контролю динамічних властивостей інерційних багатомірних промислових об’єктів. Також показана можливість автоматичної корекції похибки вимірювання температури якщо контролювати весь тепловий процес, а не його окремі значення. На прикладі вібросигналів показана можливість якісної класифікації технічних станів, а також кількісної класифікації окремих частотно-часових складових показника автокогерентності $\rho_{W}$. Доведено, що найкращими діагностичними властивостями характеризуються випадкові (шумові) складові показника автокогерентності $\rho_{W}$.
\end{abstract}

Ключов і слов а: діагностика, контроль, авто когерентність показники автокогерентності, чутливість діагностування, дискримінуючі властивості.

\section{Постановка задачі}

Мета статті - оцінка та дослідження чутливості, дискримінуючих та діагностичних властивостей показників автокогерентності на прикладі теплових та вібросигналів реального промислового об'єкту контролю та діагностування.

\section{1. Оцінка чутливості кореляційно- спектральної моделі показника автокогерентності багатовимірного термодинамічного процесу}

Обраний для дослідження об’єкт є типовим промисловим агрегатом, який використовується на виробництві. Для подібних промислових об'єктів є характерними два види процесів - регулярні низькочастотні, та періодичні високочастотні. Кожний процес характерний для конкретного вузла агрегату, проте може бути описаним за допомогою моделей одного типу. Розроблені моделі для здійснення контролю (діагностування) необхідно перевірити на адекватність. Для регулярних низькочастотних процесів здійснюємо оцінку чутливості кореляційно-спектральної моделі показника автокогерентності. Така оцінка проведена для повної моделі показника $\rho_{W}$ автокогерентності, осередненого одночасно за частотою та часом спостереження термодинамічного процесу.

Показник $\rho_{W}$ визначався одночасно для восьми термодинамічних процесів, що характеризують перехідні режими розігріву зон прес-екструдера за однаковий час спостереження $t<t_{H}$, де $t_{H}$ - номінальний час розігріву, за який температури зон пресекструдера досягають нормативних значень $\left(t_{H 1}, \ldots\right.$, $\left.t_{t 8}\right)$. Кожен з восьми термодинамічних процесів розігріву визначався на трьох інтервалах часу: $t_{o}=0.8 t_{t}$ ( $j$ - номер зони прес-екструдера або номер процесу зміни його температури). Одночасно з оцінкою показника $\rho_{w j}$ фіксувалася миттєві значення температури $T_{j}(\mathrm{j}=1 \ldots 8)$. На рис. 1 наведено зображення процесу розігріву $T_{3}$ (a) та його вейвлет-перетворення (б) (номінальної температури $6{ }^{\circ} \mathrm{C}$ ). Для прецен- зійного вимірювання температур використовувалися цифрові вимірювачі з платиновими перетворювачами типу ПТСВ, що були під'єднанні до вимірювального приладу за чотирьохпровідною схемою [1].

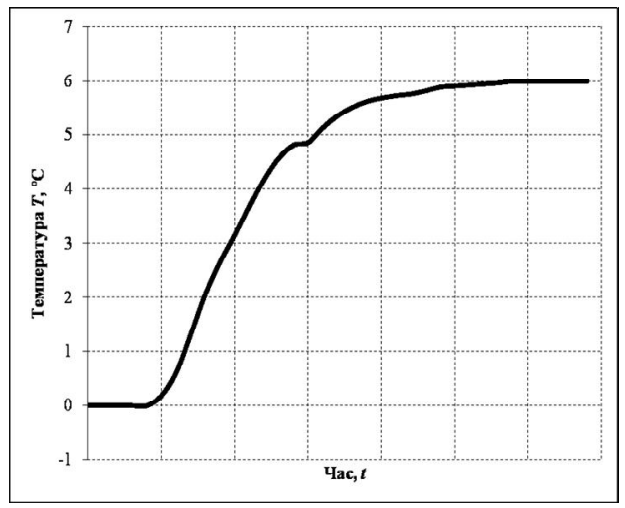

a

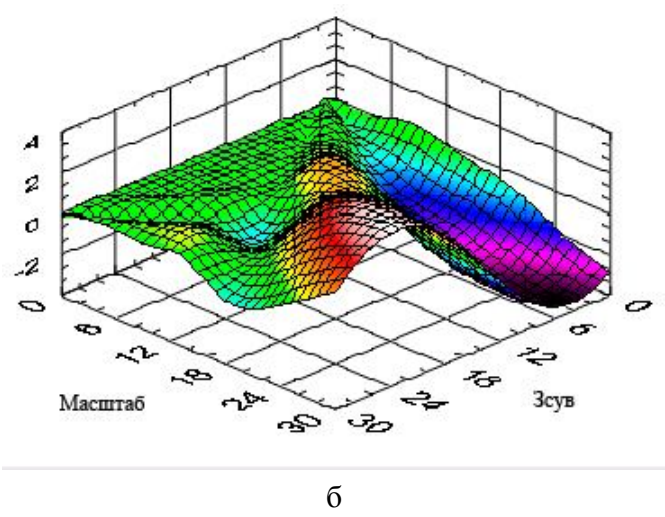

Рис. 1. Процес розігріву зони прес-екструдера $T_{3}$ (а) та його вейвлет-перетворення (б) (номінальної температури $6.00{ }^{\circ} \mathrm{C}$ )

Важливим питанням при контролі чи діагностуванні стану об'єктів $€$ визначення домінуючих параметрів, за якими безпосередньо здійснюються вказані процедури. В даному випадку, визначається домінанта 3 двох складових - функціональної складової вейвлет-коефіцієнтів та випадкової (шумової) 
складової вейвлет-коефіцієнтів. Вейвлет-аналіз спроможний виділити кожну складову.

Для визначення домінуючих параметрів при контролі чи діагностуванні на обраному для досліджень об'єкті був виконаний відповідний експеримент $з$ фіксацією термодинамічних процесів.

В табл. 1 і 2 представлені результати оцінки відповідно функціональної складової вейвлет-коефіцієнтів (характеризує математичне сподівання вейвлеткоефіцієнтів) та випадкової складової вейвлет-коефіцієнтів (характеризує дисперсію вейвлет-коефіцієнтів) спектрального вейвлет-перетворення за періоди часу $t_{H} / 3 ; 2 t_{H} / 3 ; 0.8 t_{H} ; 0.9 t_{H} ; t_{H}$. На рис. 2 продемонстровані оцінки функціональної складової вейв- лет-коефіцієнтів (а) та оцінки випадкової складової вейвлет-коефіцієнтів термодинамічних процесів $T_{2}$ та $T_{3}$ з нормативними температурами відповідно $4,9^{\circ} \mathrm{C}$ та $6{ }^{\circ} \mathrm{C}$ за масштабами та зсувами. В табл. 3 представлені результати вимірювання температур $T_{j}$ i оцінки показника автокогерентності $\rho_{w j}$ для трьох інтервалів $\Delta t_{i}(i=1 \ldots 3)$ часу спостереження:

$$
\Delta t_{1} \in\left(0 ; t_{H} / 3\right) ; \Delta t_{2} \in\left(0 ; 2 t_{H} / 3\right) ; \Delta t_{3} \in\left(0 ; 0.8 t_{H}\right) \text {. }
$$

В заголовку наведених таблиць вказані нормативні значення температур, до яких спрямовані перехідні термодинамічні процеси $T_{1}(t), \ldots, T_{8}(t)$ при $t \rightarrow \infty$.

Таблиця 1 - Результати оцінки функціональної складової вейвлет-коефіціснтів процесів розігріву зон прес-екструдера

\begin{tabular}{|c|c|c|c|c|c|c|c|c|c|}
\hline & & $\begin{array}{c}T_{1}, \text { до } \\
0.89^{\circ} \mathrm{C}\end{array}$ & $\begin{array}{r}T_{2}, \text { до } \\
4.90^{\circ} \mathrm{C}\end{array}$ & $\begin{array}{c}T_{3}, \text { до } \\
6.00{ }^{\circ} \mathrm{C} \\
\end{array}$ & $\begin{array}{r}T_{4}, \text { до } \\
6.35^{\circ} \mathrm{C} \\
\end{array}$ & $\begin{array}{r}T_{5}, \text { до } \\
6.95^{\circ} \mathrm{C} \\
\end{array}$ & $\begin{array}{c}T_{6}, \text { до } \\
44.64{ }^{\circ} \mathrm{C}\end{array}$ & $\begin{array}{c}T_{7}, \text { до } \\
45.21^{\circ} \mathrm{C} \\
\end{array}$ & $\begin{array}{c}T_{8}, \text { до } \\
64.22^{\circ} \mathrm{C} \\
\end{array}$ \\
\hline \multirow{5}{*}{ 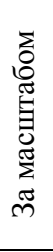 } & $t_{H} / 3$ & 0.99029 & -0.95823 & -0.98997 & -0.99750 & -0.99654 & -0.99778 & -0.99594 & -0.99746 \\
\hline & $2 t_{H} / 3$ & 0.96203 & -0.99004 & -0.99162 & -0.99434 & -0.98922 & -0.99542 & -0.98829 & -0.97633 \\
\hline & $0.8 t_{H}$ & 0.93730 & -0.97747 & -0.97649 & -0.97889 & -0.97322 & -0.97559 & -0.97116 & -0.96180 \\
\hline & $0.9 t_{H}$ & 0.88909 & -0.95019 & -0.93984 & -0.95043 & -0.93735 & -0.94476 & -0.94971 & -0.94224 \\
\hline & $t_{H}$ & 0.84132 & -0.89600 & -0.87840 & -0.91196 & -0.89051 & -0.91783 & -0.93483 & -0.92556 \\
\hline \multirow{5}{*}{ 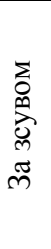 } & $t_{H} / 3$ & 0.79979 & -0.51917 & -0.65501 & -0.63786 & -0.83558 & -0.79002 & -0.88952 & -0.90569 \\
\hline & $2 t_{H} / 3$ & 0.74224 & -0.86226 & -0.87889 & -0.86230 & -0.89756 & -0.86555 & -0.89478 & -0.89292 \\
\hline & $0.8 t_{H}$ & 0.48012 & -0.75243 & -0.79422 & -0.75020 & -0.84043 & -0.76562 & -0.83376 & -0.85254 \\
\hline & $0.9 t_{H}$ & 0.77128 & -0.6497 & -0.72398 & -0.64613 & -0.79791 & -0.68332 & -0.78384 & -0.82476 \\
\hline & $t_{H}$ & 0.86285 & -0.58268 & -0.68244 & -0.58091 & -0.77551 & -0.63490 & -0.75443 & -0.81131 \\
\hline
\end{tabular}

Таблиця 2 - Результати оцінки випадкової складової вейвлет-коефіцієнтів процесів розігріву зон прес-екструдера

\begin{tabular}{|c|c|c|c|c|c|c|c|c|c|}
\hline & & $\begin{array}{c}T_{1} \text {, до } \\
0.89^{\circ} \mathrm{C}\end{array}$ & $\begin{array}{c}T_{2} \\
\text { до } 4.90^{\circ} \mathrm{C}\end{array}$ & $\begin{array}{c}T_{3}, \text { до } \\
6.00^{\circ} \mathrm{C}\end{array}$ & $\begin{array}{r}T_{4}, \text { до } \\
6.35^{\circ} \mathrm{C} \\
\end{array}$ & $\begin{array}{r}T_{5}, \text { до } \\
6.95{ }^{\circ} \mathrm{C}\end{array}$ & $\begin{array}{c}T_{6}, \text { до } \\
44.64^{\circ} \mathrm{C}\end{array}$ & $\begin{array}{c}T_{7}, \text { до } \\
45.21^{\circ} \mathrm{C}\end{array}$ & $\begin{array}{c}T_{8}, \text { до } \\
64.22{ }^{\circ} \mathrm{C}\end{array}$ \\
\hline \multirow{5}{*}{ 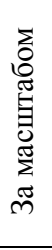 } & $t_{H} / 3$ & 0.948392 & 0.9827 & 0.990534 & 0.994543 & 0.996999 & 0.999226 & 0.998618 & 0.999426 \\
\hline & $2 t_{H} / 3$ & 0.936088 & 0.882784 & 0.914024 & 0.895846 & 0.945568 & 0.917965 & 0.951598 & 0.947412 \\
\hline & $0.8 t_{H}$ & 0.776027 & 0.622484 & 0.659852 & 0.654895 & 0.714314 & 0.684147 & 0.751091 & 0.73842 \\
\hline & $0.9 t_{H}$ & 0.632493 & 0.385449 & 0.434947 & 0.420383 & 0.504346 & 0.450934 & 0.526002 & 0.535093 \\
\hline & $t_{H}$ & 0.527761 & 0.184178 & 0.248168 & 0.211168 & 0.33262 & 0.241651 & 0.327502 & 0.365807 \\
\hline \multirow{5}{*}{ 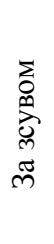 } & $t_{H} / 3$ & 0.959451 & -0.14531 & -0.10587 & -0.17015 & 0.262884 & 0.309321 & 0.789252 & 0.885281 \\
\hline & $2 t_{H} / 3$ & 0.187175 & -0.57552 & -0.59922 & -0.69047 & -0.59123 & -0.50482 & -0.18407 & -0.07328 \\
\hline & $0.8 t_{H}$ & 0.119508 & -0.6239 & -0.64611 & -0.74544 & -0.69456 & -0.62969 & -0.43302 & -0.37285 \\
\hline & $0.9 t_{H}$ & 0.14609 & -0.61118 & -0.63774 & -0.73956 & -0.59180 & -0.59182 & -0.31147 & -0.19700 \\
\hline & $t_{H}$ & 0.185628 & -0.49825 & -0.42040 & -0.55274 & -0.20140 & -0.32444 & 0.003282 & 0.129439 \\
\hline
\end{tabular}

Таблиця 3 - Значення температур та показників автокогерентності $\rho_{w j}$ для обмежених інтервалів спостереження

\begin{tabular}{|c|c|c|c|c|c|c|c|c|c|}
\hline \multirow{3}{*}{$\begin{array}{c}\text { Інтервал } \\
\text { спостере- } \\
\text { ження }\end{array}$} & \multirow{3}{*}{$\begin{array}{c}\text { Показник, що конт- } \\
\text { ролюється }\end{array}$} & \multicolumn{8}{|c|}{ Значення нормативно граничних температур $\left({ }^{\circ} \mathrm{C}\right)$ для часу $t_{\text {н }}$} \\
\hline & & $T_{1}$ & $T_{2}$ & $T_{3}$ & $T_{4}$ & $T_{5}$ & $T_{6}$ & $T_{7}$ & $T_{8}$ \\
\hline & & 0.89 & 4.90 & 6.00 & 6.35 & 6.95 & 44.64 & 45.21 & 64.22 \\
\hline$t_{H} / 3$ & \multirow{3}{*}{$\begin{array}{c}\text { Температура }\left(T_{j}\right) \text { в } \\
\text { кінці інтервалу } \\
\text { спостереження }\left({ }^{\circ} \mathrm{C}\right)\end{array}$} & 0.09 & 1.71 & 2.66 & 2.99 & 4.22 & 26.01 & 31.54 & 47.08 \\
\hline $2 t_{H} / 3$ & & 0.45 & 4.36 & 5.62 & 5.57 & 6.71 & 41.03 & 42.43 & 63.06 \\
\hline $0,8 t_{H}$ & & 0.56 & 4.66 & 5.82 & 6.08 & 6.89 & 43.41 & 44.12 & 64.02 \\
\hline $1 / 3 t_{H}$ & \multirow{3}{*}{$\begin{array}{c}\text { Показник автокоге- } \\
\text { рентності на інтер- } \\
\text { валі спостереження } \\
\left(\rho_{W j}\right)\end{array}$} & 0.376 & 0.403 & 0.518 & 0.684 & 0.612 & 0.723 & 0.835 & 0.862 \\
\hline$t_{H} / 3$ & & -0.259 & -0.174 & -0.175 & -0.148 & -0.051 & 0.054 & 0.305 & 0.369 \\
\hline $0,8 t_{H}$ & & -0.258 & 0.071 & 0.089 & 0.153 & 0.173 & 0.250 & 0.371 & 0.476 \\
\hline
\end{tabular}



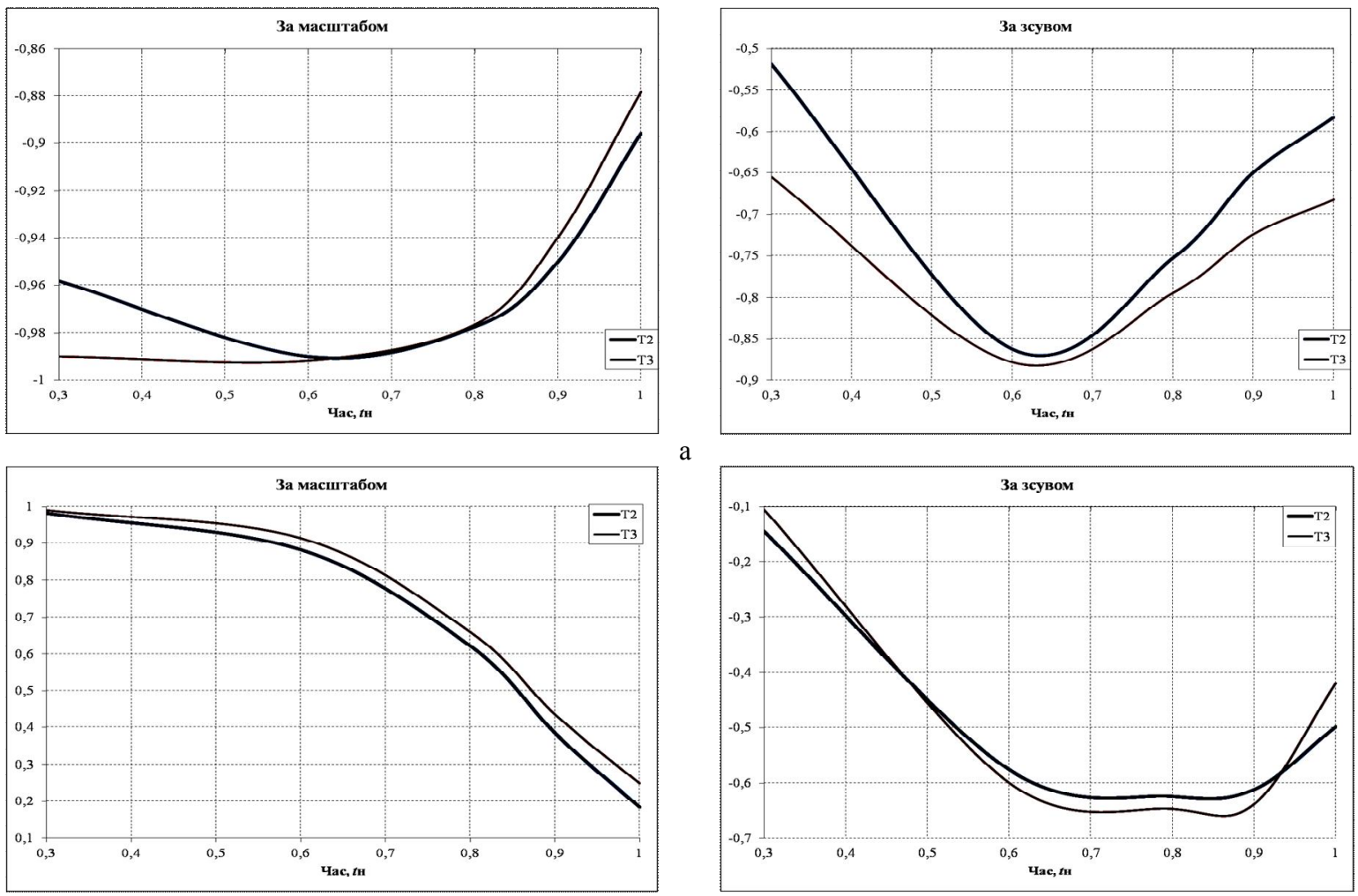

б

Рис. 2. Оцінки функціональної (а) та випадкової (б) складової вейвлет-коефіцієнтів термодинамічних процесів $T_{2}$ та $T_{3}$ з нормативними температурами відповідно $4.9^{\circ} \mathrm{C}$ та $6{ }^{\circ} \mathrm{C}$ за масштабами та зсувами

В табл. 3 контрольовані значення показників (температура і показник автокогерентності) розміщені в порядку збільшення нормативно граничних температур. Не важко помітити порушення ранжування для $T_{j}$ та $\rho_{W j}$, що відповідають стовпчикам процесів $T_{3}$ (нормативне значення температури $6^{\circ} \mathrm{C}$ ) та $T_{4}$ (нормативне значення температури $\left.6.35^{\circ} \mathrm{C}\right)$. Для зручності аналізу взяті відповідні значення показників контролю автокогерентності $\rho_{W}$, які реагують на відхилення температур (при термодинамічних порушеннях) менше ніж на $0.05^{\circ} \mathrm{C}$. Ці відхилення відповідають абсолютним середньоквадратичним похибкам в $0.1^{\circ} \mathrm{C}$ при довірчій ймовірності $P=0.95$. Така похибка забезпечується термоперетворювачами, що мають умовно клас точності (граничну зведену похибку) не нижче 0.1 , при $T=100{ }^{\circ} \mathrm{C}$. Оскільки порушення ранжування температур $T_{3}$ та $T_{4}$ відповідає умові:

$$
\delta T_{34}=T_{3}-T_{4} \geq 0.05,
$$

то контроль цих температур по показникам автокогерентності $\rho_{W 3}$ та $\rho_{W 4}$ забезпечує зменшення абсолютної похибки з величини $0.1{ }^{\circ} \mathrm{C}$ до $0.05{ }^{\circ} \mathrm{C}$, що у два рази підвищує точність вимірювального контролю термодинамічних процесів.

\section{2. Оцінка дискримінуючих властивостей показників автокогерентності при класифікації вібраційних процесів}

Збереження заданого ранжування для множини показників автокогерентності $\rho_{W}$ вказує на можли- вість використання цих показників для прогнозування граничних теплових режимів, з автоматичною корекцією температурних похибок приладів, що застосовуються при вимірюванні температури. Якщо переходити від задачі контролю динамічних властивостей до задачі розрізнення (дискримінації) технічних станів то слід використовувати об'єкт, для якого попередньо верифіковані види цих технічних станів. Більш того невизначеність миттєвих значень такого вимірювального сигналу повинна бути достатньо великою для будь-якого з досліджуваних технічних станів. В цьому сенсі найбільш зручні для дослідження є вібросигнали.

Для дослідження були використані вібросигнали, що були отримані за допомогою п'єзоелектричного вимірювального перетворювача механічної вібрації [2], який був встановлений на корпусі пари редуктор-подвоювач обраного технологічного агрегату - прес-екструдеру. Зміна вологості вхідної сировини, особливо якщо вона не відповідає нормованому значенню, зумовлює додаткові механічні навантаження в системі шнеків та редукційних механізмів. Окрім того, зниження вологості призводить до посилення ефектів спектральної нестаціонарності вібросигналів, через підвищення динамічних механічних зусиль рухомих елементів промислового об'єкту. Для дослідження були використанні три варіанти вологості вхідної сировини:

1) $8.5 \%$ - нормоване значення,

2) $8.0 \%$ - підсушена сировина,

3) $7.5 \%$ - значно підсушена сировина.

На рис. 3 представлені реалізації вібросигналів для варіантів 1 та 3 вологості вхідної сировини. 


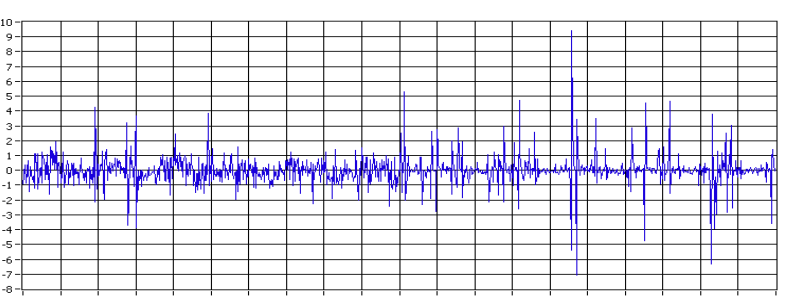

a

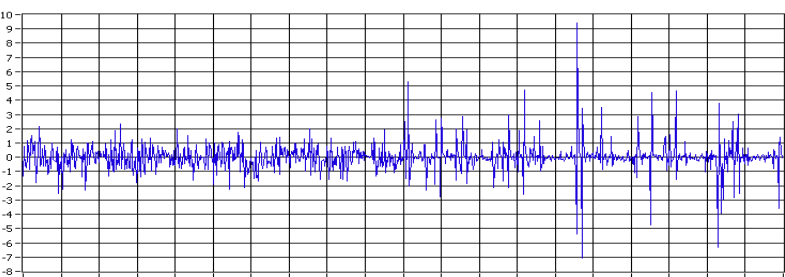

б

Рис. 3. Реалізації вібросигналів для варіантів:

1 - вологість вхідної сировини $8.5 \%$ - нормоване значення (а) та 3 - вологість вхідної сировини

$7.5 \%$ - значно підсушена сировина (б)

Складові показника автокогерентності $\rho_{W}$ позначено як $X$ з двома індексами:

- $X_{11}$ - функціональна за масштабом,

- $X_{12}$ - випадкова за зсувом,

- $X_{21}$ - функціональна за зсувом,

- $X_{22}$ - випадкова за масштабом,

- $X_{\Sigma}$ - сумарний показник автокогерентності.

Вейвлет-спектри реалізацій вібросигналів (рис. 3) представлені на рис. 4.

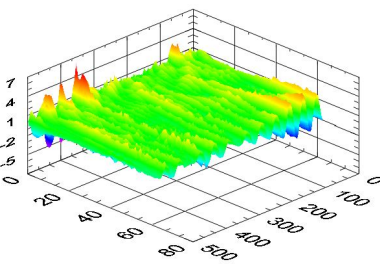

a

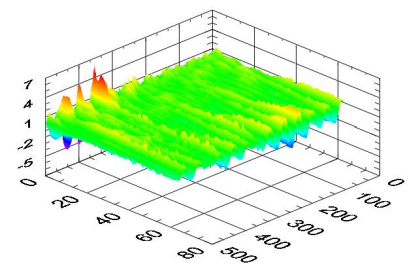

6
Рис. 4. Вейвлет-спектри реалізації вібросигналів для варіантів: 1 - вологість вхідної сировини

$8.5 \%$ - нормоване значення (а) та 3 - вологість вхідної сировини $7.5 \%$ - значно підсушена сировина

Рис. 3 та 4 практично не несуть візуальної інформації про різницю спектральних властивостей вібросигналів для 1) та 3) варіантів. Для визначення можливостей класифікаційного розрізнення вібросигналів, що належать об' єкту з різними технічними станами (нормативно заданими вологістю вхідної сировини), було проведено дисперсійний аналіз частотної та часової моделі автокогерентності 3 розкладенням коефіцієнту автокогерентності $\rho_{W}$ на параметри нестаціонарності. На рис. 5 представлені гістограми законів розподілення складових випадкових складових вейвлет-коефіцієнтів трьох варіантів вологості вхідної сировини за зсувом.

Число класифікаційних станів дорівнюе трьом (для трьох варіантів вологості вхідної сировини), кількість відліків кожного 3 вібросигналів для досліджуваних технічних станів - 2500, кількість сто- впчиків гістограм для кожного 3 трьох технічних станів - 35. Рис. 5 наглядно ілюструє принципову можливість статистичного розрізнення (класифікаціï) вібросигналів по зсуву їх законів розподілення ймовірності (гістограм).

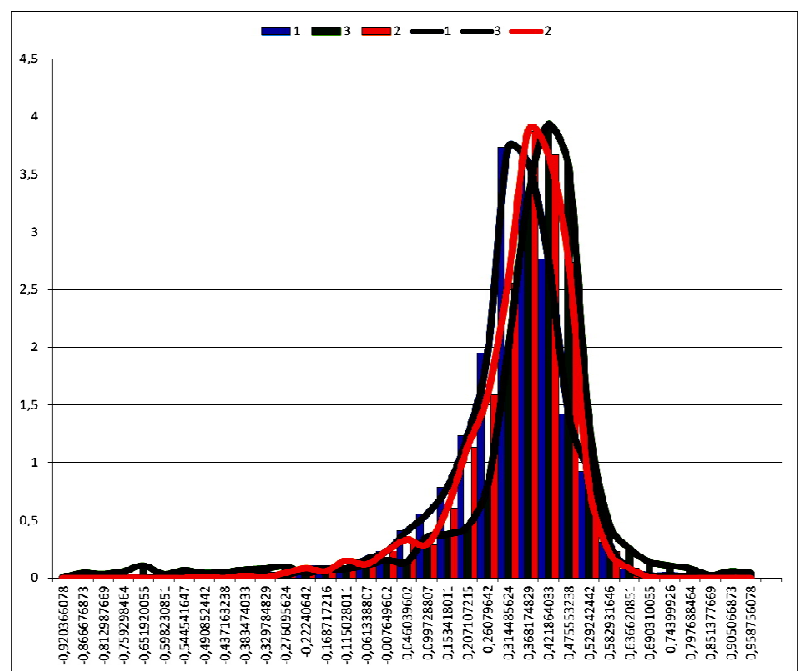

Рис. 5. Гістограми законів розподілення складових випадкових складових вейвлет-коефіцієнтів трьох варіантів вологості вхідної сировини за зсувом $\left(X_{12}\right)$

В табл. 4 представлені оцінки середніх значень і середньоквадратичних відхилень для 4-х складових показника автокогерентності $\rho_{W}$ i, власне, сумарного показника автокогерентності $\rho_{W_{\left(X_{\Sigma}\right)}}$ для класифікованих станів.

Таблицяя 4 - Оцінки середніх значень і середньоквадратичних відхилень для складових показника автокогерентності $\rho_{W}$

\begin{tabular}{|l|c|c|c|c|}
\hline \multirow{2}{*}{ № } & \multicolumn{2}{|c|}{$X_{11}$} & \multicolumn{2}{c|}{$X_{12}$} \\
\cline { 2 - 5 } & Среднее & СКО & Среднее & СКО \\
\hline 1) & $6.30572 \mathrm{E}-06$ & $1.63138 \mathrm{E}-05$ & 0.18719827 & 0.03956054 \\
\hline 2) & $-5.80514 \mathrm{E}-06$ & $2.31989 \mathrm{E}-05$ & 0.18877861 & 0.02802178 \\
\hline 3$)$ & $4.14687 \mathrm{E}-07$ & $7.3778 \mathrm{E}-06$ & 0.27819637 & 0.02730635 \\
\hline \multirow{2}{*}{ № } & \multicolumn{2}{|c|}{$X_{21}$} & \multicolumn{2}{|c|}{$X_{22}$} \\
\cline { 2 - 5 } & Среднее & СКО & Среднее & СКО \\
\hline 1) & 0.0119951 & 0.009207 & 0.175209 & 0.031107 \\
\hline 2) & 0.00861176 & 0.007233 & 0.180161 & 0.024038 \\
\hline 3) & 0.01496753 & 0.001708 & 0.263229 & 0.028013 \\
\hline \multirow{2}{*}{ № } & \multicolumn{3}{|c|}{$X_{\Sigma}$} \\
\cline { 2 - 5 } & \multicolumn{2}{|c|}{ Среднее } & СКО \\
\hline 1) & 0.187205 & 0.039559 \\
\hline 2) & \multicolumn{2}{|c|}{0.188773} & 0.028031 \\
\hline 3) & 0.278197 & 027312 \\
\hline
\end{tabular}

Результати, що представлені в табл. 4 дають можливість оцінити статистичну відстань між технічними станами у формі $T^{2}$ статистики Хотелінга [3]. Значення статистичної відстані $T^{2}$-Хотелінга за варіантами парних станів представлені в табл. 5. Табл. 5 дозволяє оцінити лінійну статистичну відстань $S_{D}$ між класифікованими станами виходячи 3 моделі спрощеного перетворення

$$
S_{D}=\sqrt{T^{2}} .
$$


В табл. 6 представлені значення статистичної відстані $S_{D}$ і розраховані, з використанням цих від-

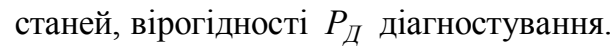

$$
P_{Д}=\Phi\left(\frac{S_{D}}{2}\right),
$$

де $\Phi(\bullet)$ - інтеграл ймовірності [4].

3 табл. 6 видно, що максимальне значення віро-

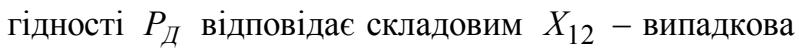
за зсувом, $X_{22}$ - випадкова за масштабом i, власне, сумарному показнику автокогерентності $\rho_{W_{\left(X_{\Sigma}\right)}}$.

Таблиця 5 - Значення статистичної відстані $T^{2}$-Хотелінга за варіантами класифікації парних станів

\begin{tabular}{|c|c|c|c|c|c|}
\hline \multirow{2}{*}{ Номер станів класифікації } & \multicolumn{5}{|c|}{ Складові показника автокогерентності $\rho_{W}$} \\
\cline { 2 - 6 } & $X_{11}$ & $X_{12}$ & $X_{21}$ & $X_{22}$ & $X_{\Sigma}$ \\
\hline 1$)-2)$ & 0.36470878 & 0.002125278 & 0.167005552 & 0.031734411 & 0.002091866 \\
\hline 2$)-3)$ & 0.130559851 & 10.44583041 & 1.462727277 & 10.12847136 & 10.4416585 \\
\hline 1$)-3)$ & 0.216514664 & 7.167309207 & 0.201521993 & 8.842315726 & 7.165769186 \\
\hline
\end{tabular}

Таблиия 6 - Значення статистичної відстані $\boldsymbol{S}_{D}$ i вірогідність $\boldsymbol{P}_{д}$ альтернативного діагностування

\begin{tabular}{|c|l|l|l|l|l|l|}
\hline \multirow{2}{*}{$\begin{array}{c}\text { Номер станів } \\
\text { класифікації }\end{array}$} & & \multicolumn{5}{|c|}{ Складові показника автокогерентості $\rho_{W}$} \\
\cline { 3 - 7 } & & \multicolumn{1}{|c|}{$X_{11}$} & \multicolumn{1}{c|}{$X_{12}$} & \multicolumn{1}{c|}{$X_{21}$} & \multicolumn{1}{c|}{$X_{22}$} & $X_{\Sigma}$ \\
\hline \multirow{2}{*}{$1)-2)$} & $S_{D}$ & 0.603911235 & 0.04610074 & 0.408663127 & 0.178141547 & 0.045736922 \\
\cline { 2 - 7 } & $P_{\text {Д }}$ & 0.6255 & 0.508 & 0.5793 & 0.5359 & 0.508 \\
\hline \multirow{2}{*}{$2)-3)$} & $S_{D}$ & 0.361330668 & 3,232000991 & 1.209432626 & 3.18252594 & 3.23135552 \\
\cline { 2 - 7 } & $P_{\text {Д }}$ & 0.5714 & $\mathbf{0 . 9 4 7 3 8}$ & 0.7257 & $\mathbf{0 . 9 4 4 0 8}$ & $\mathbf{0 . 9 4 7 3 8}$ \\
\hline \multirow{2}{*}{$1)-3)$} & $S_{D}$ & 0.465311363 & 2.677183073 & 0.44891201 & 2.973603155 & 2.676895438 \\
\cline { 2 - 7 } & $P_{\text {Д }}$ & 0.591 & 0.90988 & 0.5871 & 0.93056 & 0.90988 \\
\hline
\end{tabular}

\section{3. Дослідження діагностичних властивостей складових показника автокогерентності. Вибір показників контролю нестаціонарності}

Отримані в попередньому підрозділі оцінки вірогідності парної класифікації діагностованих технічних станів (табл. 6), мають достатньо велике зміщення. Це зумовлено практичною невідповідністю ймовірнісної моделі закону розподілення значень відповідної складової показника автокогерентності $\rho_{W}$ нормальному розподіленню імовірності. На це вказує і гістограма умовних законів розподілення складової $X_{12}$. для трьох технічних станів. Хоча, 3 іншого боку, наведені гістограми добре ілюструють значущі розходження між модами і відтак центрами умовних розподілень технічних станів 1)-3) (рис. 5).

Фактично, через локалізації значень складових показника автокогерентності $\rho_{W}[-1 ; 1]$ умовні закони розподілення їх значень відповідають моделям сплайнів [5] високого порядку (не менше п'ятого), в той час як нормально розподілені випадкові величини $\in[-\infty ; \infty]$. Виходячи зі сказаного, оцінки вірогідності табл. 6 вказують на якісну (по варіанту «маленькі-великі») різницю між складовими показника автокогерентності $\rho_{W}$. Для більш строгого, в статистичному сенсі, дослідження класифікаційних властивостей складових показника автокогерентності $\rho_{W}$ можливо застосувати математичний апарат класичного дисперсійного статистичного аналізу. Перевагою такого математичного апарату є:

- об'єктивність статистичних висновків, про відсутність або наявність класифікаційних властивостей при зміні виду технічних станів об'єкту контролю,

- можливість забезпечення заданого значення ризику класифікації (рівня значущості),
- можливість отримання оцінок кількості інформації при класифікації не тільки парних порівнюваних технічних станів, але і станів об'єднаних в нормативно задані множини (наприклад, виходячи 3 технічних умов і вимог [6]).

Використовуючи підгрупові результати оцінювання складових показника автокогерентності $\rho_{W}$, була отримана зведена табл. 7 середніх значень складових показника автокогерентності $\rho_{W}$ за кожною 3 п’яти груп для технічних станів 1), 2), 3). Для дослідження результатів, зведених в табл. 7, використаємо однофакторну параметричну модель дисперсійного аналізу [4], в якій впливаючим фактором «ВФ» є технічний стан об'єкту контролю.

Таблиця 7 - Середні значення складових показника автокогерентності $\rho_{W}$ за кожною 3 п'яти підгруп для технічних станів 1), 2), 3)

\begin{tabular}{|c|l|l|l|c|c|c|}
\hline TC & № & \multicolumn{1}{|c|}{$X_{11}$} & $X_{12}$ & $X_{21}$ & $X_{22}$ & $X_{\Sigma}$ \\
\hline \multirow{4}{*}{$1)$} & 1 & $-1.201 \mathrm{E}-06$ & 0.18787 & 0.01411 & 0.17376 & 0.18787 \\
\cline { 2 - 7 } & 2 & $2.69921 \mathrm{E}-05$ & 0.13338 & 0.00305 & 0.13036 & 0.13341 \\
\cline { 2 - 7 } & 3 & $-1.62344 \mathrm{E}-05$ & 0.16719 & 0.00261 & 0.16457 & 0.16718 \\
\cline { 2 - 7 } & 4 & $1.47554 \mathrm{E}-05$ & 0.23577 & 0.02429 & 0.21149 & 0.23578 \\
\cline { 2 - 7 } & 5 & $7.21647 \mathrm{E}-06$ & 0.21178 & 0.01592 & 0.19587 & 0.21179 \\
\hline \multirow{4}{*}{ 2) } & 1 & $-1.67254 \mathrm{E}-05$ & 0.20255 & 0.0084 & 0.19414 & 0.20254 \\
\cline { 2 - 7 } & 2 & $-1.6343 \mathrm{E}-05$ & 0.14001 & 0.00027 & 0.13972 & 0.13999 \\
\cline { 2 - 7 } & 3 & $3.18601 \mathrm{E}-05$ & 0.21091 & 0.01287 & 0.19807 & 0.21094 \\
\cline { 2 - 7 } & 4 & $-2.7555 \mathrm{E}-05$ & 0.1956 & 0.00327 & 0.1923 & 0.19557 \\
\hline \multirow{3}{*}{$3)$} & 1 & $-2.62362 \mathrm{E}-07$ & 0.19482 & 0.01825 & 0.17658 & 0.19482 \\
\cline { 2 - 7 } & 2 & $-8.31124 \mathrm{E}-05$ & 0.30719 & 0.01208 & 0.29512 & 0.30721 \\
\cline { 2 - 7 } & 3 & $-6.62393 \mathrm{E}-07$ & 0.30629 & 0.01645 & 0.28984 & 0.30629 \\
\cline { 2 - 7 } & 4 & $-4.83666 \mathrm{E}-06$ & 0.24584 & 0.01558 & 0.23026 & 0.24584 \\
\cline { 2 - 7 } & 5 & $-4.70327 \mathrm{E}-06$ & 0.26585 & 0.01488 & 0.25097 & 0.26585 \\
\hline
\end{tabular}

Моделлю результату спостереження значень обраної складової показника автокогерентності $\rho_{W}$ 
(позначимо як $Z$ ), буде вираз:

$$
z_{j i}=\bar{Z}+\delta_{j}+\varepsilon_{j i}
$$

де $z_{i j}$ - реалізація випадкової величини $Z, j-$ індекс що вказує на номер технічного стану, $i$ - номер підгрупи, що відповідає конкретному рядку табл. 7 для групи з номером $j, \bar{Z}$ - загальне середнє всіх результатів спостережень, $\delta_{j}-$ відхилення $z_{j i}$ від $\bar{Z}$, що обумовлені впливом фактором «ВФ», $\varepsilon_{j i}$ - остаточне випадкове відхилення результатів $z_{j i}$ від $\bar{Z}$ [4].

Остаточна дисперсія $z_{i j}$ - постійна, а закон розподілення відхилень $z_{i j}-$ нормальний. Дисперсійний аналіз будемо проводити окремо для кожної складової показника автокогерентності $\rho_{W}$, формуючи для цієї складової показника автокогерентності $\rho_{W}$ табл. 8, що включає в себе три строки (по виду технічного стану) і п’ять стовпчиків (по номеру підгрупи).

Таблиия 8 - Модель для дисперсійного аналізу

\begin{tabular}{|c|c|c|c|c|c|}
\hline \multirow{2}{*}{$j$} & \multicolumn{5}{|c|}{$i$} \\
\cline { 2 - 6 } & 1 & 2 & 3 & 4 & 5 \\
\hline 1 & $z_{11}$ & $z_{12}$ & $z_{13}$ & $z_{14}$ & $z_{15}$ \\
\hline 2 & $z_{21}$ & $z_{22}$ & $z_{23}$ & $z_{24}$ & $z_{25}$ \\
\hline 3 & $z_{31}$ & $z_{32}$ & $z_{33}$ & $z_{34}$ & $z_{35}$ \\
\hline
\end{tabular}

В табл. 8 номери рівнів «ВФ» відповідають номерам строк $j$. Для формування строк були використані п'ять внутрішньо групових значень (по вертикалі) для 1, 2, 3 груп, яким відповідають строки: 1 група - 3 першої по п’яту, 2 група -3 шостої по десяту, 3 група - 3 одинадцятої по п’ятнадцяту.

Отримані $F$-статистики Фішера для дисперсійного аналізу класифікаційних властивостей складових показника автокогерентності $\rho_{W}$ представлені в табл. 9. Проведений дисперсійний аналіз дозволяє перевірити основну гіпотезу $H_{0}: \delta_{i}=0$. Критичне значення $F$ відповідає умовам: значення чисел ступенів свободи дорівнює 2 і 12, рівень значущості (ризик контролю першого роду) $\alpha=0.05$.

3 табл. 9 слідує, що найкращими класифікаційними (діагностичними) властивостями [7] володіють складові $X_{22}, X_{12}$ показника автокогерентності $\rho_{W}$. Оскільки їх $F$-статистики перевищують критичне значення $F$ більше ніж в три рази $(15.7414>3.885294 ; 13.14539>3.885294)$.

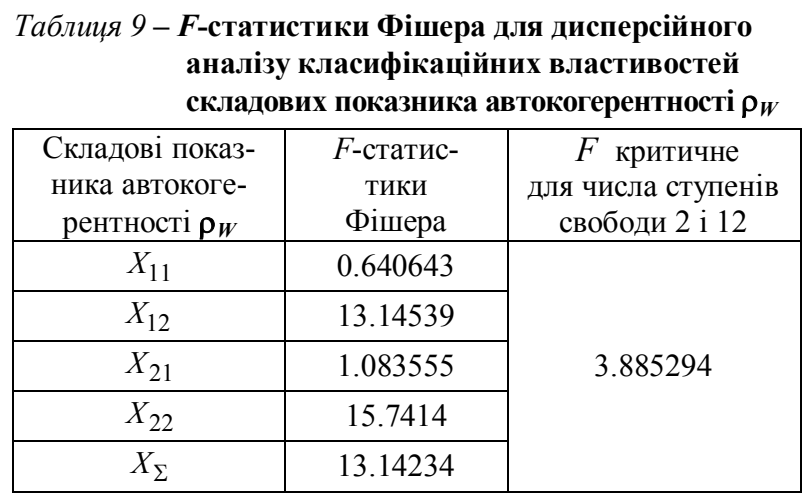

Такою ж перевагою володіє і власне показник автокогерентності $\rho_{W_{\left(X_{\Sigma}\right)}}(13.14234>3.885294)$.

Оскільки дані складові показника автокогерентності $\rho_{W}$ характеризують випадкові (шумові) зміни спектру, це вказує, що основною моделлю нестаціонарності вимірювальних випадкових вібраційних сигналів є модель спектральної нестаціонарності за випадковими (шумовими) залишковими змінами вейвлетспектру [8]. Функціональна змінність вейвлет-спектрів інформацію про зміну технічних станів не несе. Для дослідження інформативної незалежності складових $X_{11}, X_{12}, X_{21}, X_{22}, \rho_{W_{\left(X_{\Sigma}\right)}}$ була розрахована кореляційна матриця (табл. 10) на базі табл. 7.

Таблиия 10 - Кореляційна матриця

\begin{tabular}{|l|c|c|c|c|c|}
\hline & $X_{11}$ & $X_{12}$ & $X_{21}$ & $X_{22}$ & $X_{\Sigma}$ \\
\hline$X_{11}$ & 1.000000000 & 0.117131872 & 0.379338687 & 0.073957477 & 0.117437781 \\
\hline$X_{12}$ & 0.117131872 & 1.000000000 & 0.626352736 & 0.994049080 & 0.9999999953 \\
\hline$X_{21}$ & 0.379338687 & 0.626352736 & 1.000000000 & 0.537707993 & 0.626447610 \\
\hline$X_{22}$ & 0.073957477 & 0.994049080 & 0.537707993 & 1.000000000 & 0.994035858 \\
\hline$X_{\Sigma}$ & 0.117437781 & 0.999999953 & 0.626447610 & 0.994035858 & 1.000000000 \\
\hline
\end{tabular}

Будь-яка $F$-статистика однофакторного дисперсійного аналізу пов'язана з квадратом коефіцієнту парної кореляції рівнянням [9]:

$$
F_{1, n-2}=\frac{R^{2}}{1-R^{2}}(n-2),
$$

де $n=15$ (число строк таблиці 7).

3 рівняння (6) випливає, що гіпотеза $H_{0}$ не відкидається (складові показника автокогерентності $\rho_{W}$ не корельовані між собою - інформація незалежна) якщо парна кореляція менше або дорівнює критичному значенню:

$$
R_{\kappa p}=\sqrt{F_{\kappa p} /\left(n+F_{\kappa p}-2\right)}=0.4797 .
$$

В іншому випадку гіпотеза $H_{0}$ відкидається (складові показника автокогерентності $\rho_{W}$ корельовані між собою - інформація залежна).

3 аналізу кореляційної матриці (табл. 10) найбільш інформативні є складові $X_{12}$ та $X_{22}$ показника автокогерентності $\rho_{W}$. Складову $X_{22}$ показника автокогерентності $\rho_{W}$ можна застосовувати тільки однією, т.я. вона сильно корельована $з$ іншими складовими показника автокогерентності $\rho_{W}$. 


\section{Висновки}

На прикладі теплових динамічних процесах показана ефективність розробленого показника автокогерентності $\rho_{W}$ для задач контролю динамічних властивостей інерційних багатомірних промислових об'єктів. Також показана можливість автоматичної корекції похибки вимірювання температури якщо контролювати весь тепловий процес, а не його окремі значення (табл. 3).
На прикладі вібросигналів показана можливість якісної класифікації (рис. 5) технічних станів, а також кількісної класифікації окремих частотночасових складових показника автокогерентності $\rho_{W}$ (табл. 6). Доведено, що найкращими діагностичними властивостями характеризуються випадкові (шумові) складові показника автокогерентності $\rho_{W}$ (табл. 6 і 9).

\section{СПИСОК ЛІТЕРАТУРИ}

1. Термоперетворювачі опору. Загальні технічні вимоги і методи випробування: ДСТУ 2858:2015. - [Чинний від 201707-01]. - К. : Держстандарт України 2017. - 21 с. - (Національний стандарт України)

2. Патент № 116115 України, G01H 1/16 П’єзоелектричний вимірювальний перетворювач механічної вібрації / Сокол Є.І., Щапов П.Ф., Мигущенко Р.П., Бойко В.В., Замятін П.М., Кропачек О.Ю., Замятін Д.П., Коржов І.М. - Заявл. 11.11.16; Опубл. 10.05.17, Бюл. № 9.

3. Захожай В.Б. Статистика якості / В.Б. Захожай, А.Ю. Чорний. - К.: МАУП, 2005. - 576 с.

4. Джонсон Н. Статистика и планирование эксперимента в технике и науке: Методы планирования эксперимента / Н. Джонсон, Ф.Лион; пер. $з$ англ. під ред. Е. К. Лецького. - М.: Мир, 1981. - 520 с.

5. Роджерс Д., Адамс Дж. Математические основы машинной графики. - М.: Мир, 2001. — 604 с.

6. Технічне діагностування та контроль технічного стану. Терміни та визначення: ДСТУ 2389-94. - [Чинний від 199501-01]. - К.: Держстандарт України 1994. - 24 с. - (Національний стандарт України).

7. Коржов І. М. Дослідження кореляційних моделей спектральної нестаціонарності випадкових сигналів / П. Ф. Щапов, Р. П. Мигущенко, О. Ю. Кропачек, І. М. Коржов // Метрологія та прилади. - 2018. - №5 (73). - С. 11 - 14.

8. Коржов I. М. Аналіз моделей функції когерентності спектральної нестаціонарності випадкових сигналів / I.M. Коржов // Вісник Національного технічного університету «ХПІ». - Х.: НТУ «ХПІ», 2018. - № 46 (1322). - С. 30 - 34.

9. Щапов П.Ф. Методи підвищення вірогідності контролю та діагностики стохастичних параметрів об'єктів різної фізичної природи: дис. докт. техн. наук: 05.11.13 / Щапов Павло Федорович. - Харків, 2009. - 368 с.

Рецензент: д-р техн. наук, проф. О. О. Можаєв, Харківський національний університет внутрішніх справ, Харків Received (Надійшла) 28.11.2018 Accepted for publication (Прийнята до друку) 23.01.2019

\section{Оценка и исследования чувствительности, дискриминирующих и диагностических свойств показателей автокогерентности}

\section{И. М. Коржов, П. Ф. Щапов, Р. П. Мигущенко, О. Ю. Кропачек}

Проведена оценка чувствительности корреляционно-спектральной модели показателя автокогерентности многомерного термодинамического процесса, оценка дискриминирующих свойств показателей автокогерентности при классификации вибрации, исследовано диагностические свойства составляющих показателя автокогерентности на примере тепловых и вибросигналов реального промышленного объекта контроля и диагностирования. На примере тепловых динамических процессах показана эффективность разработанного показателя автокогерентности $\rho_{W}$ для задач контроля динамических свойств инерционных многомерных промышленных объектов. Также показана возможность автоматической коррекции погрешности измерения температуры если контролировать весь тепловой процесс, а не его отдельные значения. На примере вибросигналов показана возможность качественной классификации технических состояний, а также количественной классификации отдельных частотно-временных составляющих показателя автокогерентности $\rho_{W}$. Доказано, что лучшими диагностическими свойствами характеризуются случайные (шумовые) составляющие показателя автокогерентности $\rho_{W}$.

Ключевые слов а: диагностика, контроль, автокогерентность показатели автокогерентности, чувствительность диагностики, дискриминирующие свойства.

\section{Assessment and study of sensitivity, discriminating and diagnostic properties of autocogenerative indicators}

I. Korzhov, P. Shchapov, R. Mygoshchenko, O. Kropachek

The estimation of the sensitivity of the correlation spectral model of the auto-coherence index of the multidimensional thermodynamic process, the evaluation of the discriminating properties of the autocogeneration indices in the classification of vibration processes, the diagnostic properties of the components of the auto-coherence index on the example of the thermal and vibration signals of the real industrial object of control and diagnostics are investigated. The example of thermal dynamic processes shows the efficiency of the developed autocorrelation index $\rho_{W}$ for problems of controlling the dynamic properties of inertial multidimensional industrial objects. Also shown is the possibility of automatic correction of the measurement error of temperature if control of the entire heat process, and not its individual values. The example of vibration signals shows the possibility of qualitative classification of technical states, as well as the quantitative classification of individual frequency-time components of the auto-coherence index $\rho_{W}$. It is proved that the best diagnostic properties are characterized by random (noise) components of the auto-coherence index $\rho_{W}$.

Keywords : diagnostics, control, auto-coherence, auto-coherence indices, diagnostic sensitivity, discriminating properties. 